\title{
Mechanism of Inhibitory Effect of Tricyclazole on Secondary Infection by Spores of Pyricularia oryzae
}

\author{
Tetsuro Okuno, Yoshiharu Kitamura and Kazuho Matsuura \\ Research Laboratories, Agricultural Chemicals Division, Takeda Chemical Industries, \\ Ichijoji, Sakyo-ku, Kyoto 606, Japan
}

(Received January 18, 1983)

Several fungicides used for the control of rice blast disease have been revealed to inhibit melanin biosynthesis in Pyricularia oryzae at the concentration not affecting vegetative growth of the fungus. ${ }^{1,2)}$ The fungicides including tricyclazole [5-methyl-1,2,4-triazolo(3,4-b) benzothiazole] inhibit appressorial penetration probably due to the lack of melanization in appressoria. $^{3)}$ The other modes of action of tricyclazole in rice blast control were reported as inhibition of secondary infection by spores resulting from suppression of spore formation $^{4)}$ and the decrease of spore pathogenicity ${ }^{4}$ and from the production of antifungal substance in rice plants. ${ }^{5)}$ In this paper we studied the effect of tricyclazole on the appressorial penetration of spores of $P$. oryzae, formed de novo in the presence of the chemical.

Pyricularia oryzae Cav., P-2 successively cultured on a V-8 juice agar medium ${ }^{3)}$ and on rice plants was used. Rice plants (Oryza sativa cv., Asahi \#4) were grown in pots $(9 \mathrm{~cm}$ in diameter) in a greenhouse at $25 \pm 3^{\circ} \mathrm{C}$ under natural day light. To obtain spores formed on the rice leaves treated with tricyclazole, four week-old healthy plants were put in a moist chamber at $27^{\circ} \mathrm{C}$ together with infected plants as an inoculum for 4 days and then treated with the chemical solution (100 $\mathrm{ml}$ per pot) using spray gun; spores formed during incubation for inoculation were washed away during the treatment. The plants treated with the chemical solution were dried and placed in a moist chamber at $30^{\circ} \mathrm{C}$ overnight for formation of spores. Spores formed on the leaves treated with tricyclazole and those formed on the V-8 juice agar medium containing the chemical were collected with a brush and washed three times with deionized sterile water containing $200 \mu \mathrm{g} /$ $\mathrm{ml}$ streptomycin (DWS) by centrifugation. The spores were incubated on cellulose membrane and penetration from appressoria was observed as described. ${ }^{3)}$

The spores formed on the V-8 juice agar medium containing tricyclazole at concentrations higher than $0.5 \mu \mathrm{g} / \mathrm{ml}$ produced hyaline appressoria on the cellulose membrane resembling those produced from spores incubated in the presence of tricyclazole. The hyaline appressoria did not develop infection hyphae from appressoria and failed to penetrate cellulose membrane (Table 1).

Spores formed on the leaves sprayed with $100 \mu \mathrm{g} / \mathrm{ml}$ tricyclazole produced hyaline appressoria with no ability to penetrate cellulose membrane (Table 2). The frequency of appressorial penetration increased with decreasing tricyclazole concentrations used for the leaf treatment.

The results presented in this report indicate that tricyclazole moved systemically into spores formed de novo on the rice leaves treated with tricyclazole and on the V-8 juice agar medium containing the chemical and that tricyclazole concentration in the spores should be high enough to inhibit melanin biosynthesis in appressoria produced from the spores and to inhibit appressorial penetration. This mode 
Table 1 Pigmentation of appressoria and penetration from appressoria in spores of Pyricularia oryzae formed on V-8 agar medium containing tricyclazole. ${ }^{\text {a }}$

\begin{tabular}{ccc}
\hline $\begin{array}{c}\text { Concentration } \\
\text { of } \\
\text { tricyclazole } \\
(\mu \mathrm{g} / \mathrm{ml})\end{array}$ & $\begin{array}{c}\text { Pigmentation } \\
\text { of } \\
\left.\text { appressoria }^{\mathrm{b}}\right)\end{array}$ & $\begin{array}{c}\text { Penetration } \\
\text { from } \\
\text { appressoria }) \\
(\%)\end{array}$ \\
\hline 0 & + & 47 \\
0.1 & + & 48 \\
0.5 & \pm & 5 \\
1 & - & 4 \\
5 & - & 2 \\
10 & - & 0 \\
25 & - & 0 \\
50 & - & 0 \\
100 & - & 0 \\
\hline
\end{tabular}

a) Spores were prepared from 5-day culture.

b) Expressed as black appressoria $(+)$, hyaline appressoria $(-)$ and intermediate $( \pm)$.

c) Determined after $96 \mathrm{hr}$ of incubation.

Table 2 Pigmentation of appressoria and penetration from appressoria in spores of Pyricularia oryzae formed on the rice plant leaves treated with tricyclazole.

\begin{tabular}{ccc}
\hline $\begin{array}{c}\text { Concentration } \\
\text { of } \\
\text { tricyclazole } \\
(\mu \mathrm{g} / \mathrm{ml})\end{array}$ & $\begin{array}{c}\text { Pigmentation } \\
\text { of } \\
\left.\text { appressoria }^{\mathrm{a}}\right)\end{array}$ & $\begin{array}{c}\text { Penetration } \\
\text { from } \\
\left.\text { appressoria }^{\mathrm{b}}\right) \\
(\%)\end{array}$ \\
\hline 0 & + & 56 \\
6.3 & + & 55 \\
12.5 & + & 42 \\
25 & + & 22 \\
50 & \pm & 15 \\
100 & - & 0
\end{tabular}

a) See footnote to Table 1 .

b) Determined after $120 \mathrm{hr}$ of incubation. of action of tricyclazole will explain the decrease of the virulence of spores in secondary infection and this will be one of the causative factors of the anti-blast control effect of tricyclazole in secondary infection together with the reduction in spore density. ${ }^{4)}$

\section{REFERENCES}

1) C. P. Woloshuk \& H. D. Sisler: J. Pesticide Sci. 7, 161 (1982)

2) I. Yamaguchi, S. Sekido \& T. Misato: J. Pesticide Sci. 7, 523 (1982)

3) T. Okuno, K. Matsuura \& I. Furusawa: J. Pesticide Sci. 8, 357 (1983)

4) Y. Kitamura, K. Yakushiji \& O. Wakae: Ann. Phytopathol. Soc. Jpn. 42, 370 (Abstract) (1976)

5) Y. Shiba \& T. Nagata: Ann. Phytopathol. Soc. Jpn. 47, 662 (1981)

\section{要 約}

\section{Tricyclazole のいもち病菌胞子二次感染阻止 機構}

奥野哲郎, 北村吉覇, 松浦一穂 tricyclazole ( $0.5 \mu \mathrm{g} / \mathrm{ml}$ 以上) を含む寒天培地上に形 成されたいもち病菌胞子は透明な付着器をセルロース膜 上に形成した. この付着器は膜侵入能を欠いていた. tricyclazole $(100 \mu \mathrm{g} / \mathrm{ml})$ 噴霧処理イネ葉上に形成された 胞子もセルロース膜上に膜侵入能をもたない透明な付着 器を形成した. これらの結果は tricyclazole 存在下で形 成された胞子中に薬剤が浸透移行し，さらにその胞子よ り形成される付着器の黒色化(メラニン化)を阻害するこ と, およびその結果として付着器からの侵入を阻害する ことを示している.このことがこれまで二次感染阻害作 用として報告されてきた本楽剤の作用特性の一部を説明 するものと思われる. 